\title{
Nano hydroxyapatite-blasted titanium surface creates a biointerface able to govern Src-dependent osteoblast metabolism as prerequisite to ECM remodeling
}

\author{
Célio J.C. Fernandes ${ }^{\mathrm{a}, 1}$, Fábio Bezerra ${ }^{\mathrm{a}, 1}$, Marcel R. Ferreira ${ }^{\mathrm{a}, 1}$, Amanda F.C. Andrade ${ }^{\mathrm{a}}$, \\ Thais Silva Pinto ${ }^{a}$, Willian F. Zambuzzi ${ }^{\mathrm{a}, \mathrm{b}, *}$ \\ a Department of Chemistry and Biochemistry, Bioscience Institute, São Paulo State University, UNESP, Campus Botucatu, Botucatu, São Paulo, Brazil \\ ${ }^{\mathrm{b}}$ Electron Microscopy Center, IBB, UNESP, Botucatu, SP, Brazil
}

\section{A R T I C L E I N F O}

\section{Article history:}

Received 21 September 2017

Received in revised form

21 December 2017

Accepted 27 December 2017

Available online 28 December 2017

\section{Keywords:}

Biointerfaces

Biotechnology

Nanotechnology

Hydroxyapatite

Implants

Osteoblast

Adhesion

Signal transduction

\begin{abstract}
A B S T R A C T
Over the last several years, we have focused on the importance of intracellular signaling pathways in dynamically governing the biointerface between pre-osteoblast and surface of biomaterial. Thus, this study investigates the molecular hallmarks involved in the pre-osteoblast relationship with different topography considering Machined (Mc), Dual Acid-Etching (DAE), and nano hydroxyapatite-blasted (nHA) groups. There was substantial differences in topography of titanium surface, considering Atomic Force Microscopy and water contact angle ( $\mathrm{Mc}=81.41 \pm 0.01$; $\mathrm{DAE}=97.18 \pm 0.01 ; \mathrm{nHA}=40.95 \pm 0.02$ ). Later, to investigate their topography differences on biological responses, pre-osteoblast was seeded on the different surfaces and biological samples were collected after $24 \mathrm{~h}$ (to consider adhesion signaling) and 10 days (to consider differentiation signaling). Preliminary results evidenced significant differences in morphological changes of pre-osteoblasts mainly resulting from the interaction with the DAE and nHA, distinguishing cellular adaptation. These results pushed us to analyze activation of specific genes by exploring qPCR technology. In sequence, we showed that Src performs crucial roles during cell adhesion and later differentiation of the pre-osteoblast in relationship with titanium-based biomaterials, as our results confirmed strong feedback of the Src activity on the integrin-based pathway, because integrin- $\beta 1$ ( $\sim 5$-fold changes), FAK ( $\sim 12$-fold changes), and Src $(\sim 3.5$-fold changes) were significantly up-expressed when Src was chemically inhibited by PP1 $(5 \mu \mathrm{M})$. Moreover, ECM-related genes were rigorously reprogrammed in response to the different surfaces, resulting on Matrix Metalloproteinase (MMP) activities concomitant to a significant decrease of MMP inhibitors. In parallel, we showed PP1-based Src inhibition promotes a significant increase of MMP activity. Taking all our results into account, we showed for the first time nano hydroxyapatite-blasted titanium surface creates a biointerface able to govern Src-dependent osteoblast metabolism as pre-requisite to ECM remodeling
\end{abstract}

(C) 2017 Elsevier B.V. All rights reserved.

\section{Introduction}

Biomedical implants are one of the most common therapies used in case of bone lesions. Although several materials have been considered to produce these metallic devices, titanium is considered the gold standard [1]. Mechanistically, the success of the therapy using these biomaterials can be evaluated by the profile of osteoin-

\footnotetext{
* Corresponding author at: Dept. of Chemistry and Biochemistry Biosciences Institute/IBB-UNESP, P.O. Box: 510, Zip Code: 18618-970 Rubião Jr, Botucatu, São Paulo, Brazil.

E-mail address: wzambuzzi@ibb.unesp.br (W.F. Zambuzzi).

1 These authors contributed equally in this work.
}

tegration promoted by the osteoprogenitor cells in response to them. It is known that the physico-chemical properties of the biomaterial surfaces decisively trigger biological phenomena able to modulate cellular response and later impact the time and quality of osseointegration [2-4]. Therefore, a special look at cellular transducers that govern cell-biomaterial response becomes necessary.

Intracellular signaling pathways triggered upon integrin activation are classical biomarkers of the eukaryotic cell adhesion, and focal adhesion kinase (FAK) and product of the transforming gene of Rous sarcoma virus, Src, are important intracellular proteins to link integrin activation with cytoskeleton rearrangement [5-7]. In detail, integrins are transmembrane proteins responsible for cell anchoring in substrata, such as extracellular matrix compo- 
nents [8]. When activated, integrins recruit FAK and Src molecules leading to a specific intracellular pathway culmination in different responses such as cytoskeletal rearrangement, cell proliferation, motility, differentiation, and survival, as discussed elsewhere [9]. Thus, understanding the biomaterial biointerface able to favor cell interactions is an interesting strategy to contribute to biomedical engineering and biotechnological business.

It is already known that for a complete biomaterial osseointegration a well-orchestrated ECM remodeling peri-implant is necessary $[10,11]$. As important proteases in this context, matrix metalloproteinases (MMPs) are proteins responsible for degradation of the ECM components and are fundamental for adequate remodeling [12]. On the other hand, tissue inhibitor of matrix metalloproteinases (TIMP's) and reversion-inducing cysteine rich protein with Kazal motifs (RECK) are important modulators of MMP activities, and are required to orchestrate ECM remodeling [13,14].

Summarizing, we investigated the molecular hallmarks involved with the pre-osteoblast relationship with different topography considering Machined (Mc), Dual acid-etching (DAE), and nano hydroxyapatite-blasted (nHA) groups. We showed Src performs crucial roles during cell adhesion and later differentiation of the pre-osteoblast in relationship with titanium-based biomaterials, because our results confirmed a strong feedback of the Src activity on the integrin-based pathway as integrin- 11 ( $\sim 5$-fold changes), FAK ( $\sim 12$-fold changes), and Src ( 3,5-fold changes) were significantly up-expressed when Src was chemically inhibited by PP1. Moreover, ECM remodeling-related genes were rigorously reprogrammed in response to the different surfaces, resulting on Matrix Metalloproteinase (MMPs) activities inverse to Src expression, suggesting Src as a suppressor of MMP processing.

\section{Material and methods}

\section{Materials}

Three different titanium surfaces (discs) were investigated in this study, distinguishing by the surface properties, called Machined (Mc; control), Dual Acid-Etched (DAE), and acid-etched nanoHA-blasted (nHA). The nHA was obtained by using the Promimic HAnano-method, a detailed description can be found elsewhere [15-17]. Briefly, the samples were dipped into a stable particle suspension containing $10 \mathrm{~nm}$ in diameter HA particles followed by a heat treatment at $550^{\circ} \mathrm{C}$ for $5 \mathrm{~min}$ in nitrogen atmosphere. The surfactant-mediated process allows better control of the chemical composition of the coating [16]. The primers used in this study were purchased from Exxtend company (Campinas, São Paulo, Brazil). The antibodies were purchased from Cell Signalling Technology (Boston, MA, USA). All the titanium materials were sterilized by exposure to Gamma irradiation and donated by S.I.N. - Sistema Nacional de Implantes (São Paulo, SP, Brazil).

\subsection{Surface characterization of the materials}

\subsubsection{Atomic force microscopy (AFM)}

Ti-modified surfaces were first processed by AFM, in which AFM tip acts as a "nano profilometer" and is able to generate information on the micro and nano-dimensional aspects of the surface $(\mathrm{x}$, $\mathrm{y}$, and $\mathrm{z}$ axis). The images were acquired by using Bioscope Catalyst (Bruker Coorp) equipment, and AFM cantilevers, also from Bruker, ("RTESPA", $\mathrm{k}=20$ to $80 \mathrm{~N} / \mathrm{m}$ ) were used. The equipment worked in intermittent contact mode and images were taken from 3 different samples (Machined, Double-Acid Etched, and nano Hydroxyapatite) and 3 different regions on each sample (border, middle, and opposite border). Scans of $3.3 \times 3.3 \mu \mathrm{m}^{2}$ were taken to check homogeneity.

\subsubsection{Water contact angle}

An automated goniometer (Ramé Hart, 100-00) was used to evaluate water wettability through contact angle measurements. Deionized water and diiodomethane were used as probe liquids and the presented results correspond to the average of 10 measurements.

\subsubsection{Cell culture}

MC3T3-E1 (subclone 4), mouse pre-osteoblastic cells, was used in this study. Pre-osteoblasts were cultured in $\alpha$-MEM supplemented with $10 \%$ Fetal Bovine Serum (FBS) at $37^{\circ} \mathrm{C}$ and $5 \% \mathrm{CO}_{2}$. Sub-confluent passages were tripsinized and used in all experiments. For the collect samples, the cells were seeded on the titanium surfaces (direct contact) or treated with the titaniumenriched medium (prepared according to the ISO 10993: 2016) up to $24 \mathrm{~h}$ (for the adhesion evaluation) and up to 14 days (for the osteogenic phenotype). During this time, the cells were maintained at $37^{\circ} \mathrm{C}$ in conditioned medium. The culture medium was changed every 3 days to provide an adequate concentration of nutrients to the cells. To understand whether Src was affecting the feedback of adhesion-related genes, pre-osteoblast was treated up to $24 \mathrm{~h}$ with PP1 $(5 \mu \mathrm{M})$, when the total RNA and protein extract were collected.

The efficiency of PP1 was determined by immunoblotting. Briefly, the cells were lysed $(50 \mathrm{mM}$ Tris [tris(hydroxymethyl)aminomethane]-HCl [pH 7.4], 1\% (vol/vol) Tween 20, 0.25\% sodium deoxycholate, $150 \mathrm{mM} \mathrm{NaCl}, 1 \mathrm{mM}$ EGTA (ethylene glycol tetraacetic acid), $1 \mathrm{mM} O$-Vanadate, $1 \mathrm{mM} \mathrm{NaF}$, plus protease inhibitors $[1 \mu \mathrm{g} / \mathrm{mL}$ aprotinin, $10 \mu \mathrm{g} / \mathrm{mL}$ leupeptin, and $1 \mathrm{mM}$ 4-(2-amino-ethyl)-benzolsulfonyl-fluor-hydrochloride] and kept on ice for $2 \mathrm{~h}$. After clearing the lysate by centrifugation, the amount of protein obtained was determined using Lowry's method. Afterwards, an equal volume of $2 \times$ sodium dodecyl sulfate (SDS) gel loading buffer (100 mM Tris- $\mathrm{HCl}$ [pH 6.8], $200 \mathrm{mM}$ dithiothreitol [DTT], 4\% SDS, $0.1 \%$ bromophenol blue, and $20 \%$ glycerol) was added to samples, which were then boiled for $5 \mathrm{~min}$. Proteins were resolved by SDS-polyacrylamide gel electrophoresis (SDS-PAGE) and transferred to PVDF membranes. Then, membranes were blocked with either $1 \%$ fat-free dried milk or bovine serum albumen (2.5\%) in $1 \times$ Tris-buffered saline (TBS)-Tween $20(0.05 \%, \mathrm{vol} / \mathrm{vol})$ and incubated overnight at $4{ }^{\circ} \mathrm{C}$ with appropriate primary antibody at 1:1000 dilutions. After washing in $3 \times$ TBS-Tween 20, membranes were incubated with horseradish peroxidase-conjugated anti-rabbit IgGs antibodies, at 1:2000 dilutions (in all immunoblotting assays), in blocking buffer for $1 \mathrm{~h}$. After washing in $3 \mathrm{x}$ TBS, the detection was performed by using enhanced chemiluminescence (ECL) [29].

\subsection{Scanning electron microscopy (SEM)}

Pre-osteoblasts were seeded on different titanium surfaces at the density of $5 \times 10^{4}$ cells/disc. After $4 \mathrm{~h}$, cells were fixed with $2.5 \%$ of glutaraldehyde in $0.1 \mathrm{M}$ phosphate buffer $\mathrm{pH} 7.3$ for $24 \mathrm{~h}$. They were immersed in osmium tetroxide $0.5 \%$ for $40 \mathrm{~min}$, dehydrated with a series of alcohols, dried at a critical point, and finally metallized. Samples were studied using a Quanta 200 - FEI Company scanning electron microscope at an accelerating voltage of $12.5 \mathrm{kV}$.

\subsection{Quantitative PCR assay ( $q P C R)$}

Cells were directly cultured on different texturized titanium surfaces and after $24 \mathrm{~h}$ or 14 days, the total RNA was extracted from cells with Ambion TRIzol Reagent (Life Sciences - Fisher Scientific Inc, Walthan, MA, USA) and treated with DNase I (Invitrogen, Carlsband, CA, USA). cDNA synthesis was performed with High Capacity cDNA Reverse Transcription Kit (Applied Biosystems, Foster City, CA, USA) according to the manufacturer's instructions. qPCR was 
Table 1

Expression primers sequences and qPCR cycle conditions.

\begin{tabular}{|c|c|c|c|}
\hline Gene & Primer & 5'-3' Sequence & Reactions Condition \\
\hline MMP2 & $\begin{array}{l}\text { Forward } \\
\text { Reverse }\end{array}$ & $\begin{array}{l}\text { AACTTTGAGAAGGATGGCAAGT } \\
\text { TGCCACCCATGGTAAACAA }\end{array}$ & $95^{\circ} \mathrm{C}-15 \mathrm{~min} ; 95^{\circ} \mathrm{C}-15 \mathrm{~s} ; 60^{\circ} \mathrm{C}-30 \mathrm{~s} ; 72^{\circ} \mathrm{C}-20 \mathrm{~s}$ \\
\hline MMP9 & $\begin{array}{l}\text { Forward } \\
\text { Reverse }\end{array}$ & $\begin{array}{l}\text { TGTGCCCTGGAACTCACACGAC } \\
\text { ACGTCGTCCACCTGGTTCACCT }\end{array}$ & $95^{\circ} \mathrm{C}-15 \mathrm{~min} ; 95^{\circ} \mathrm{C}-15 \mathrm{~s} ; 60^{\circ} \mathrm{C}-30 \mathrm{~s} ; 72^{\circ} \mathrm{C}-20 \mathrm{~s}$ \\
\hline TIMP1 & $\begin{array}{l}\text { Forward } \\
\text { Reverse }\end{array}$ & $\begin{array}{c}\text { ATCCTCTTGTTGCTATCACTG } \\
\text { GGTCTCGTTGATTTCTGGG }\end{array}$ & $95^{\circ} \mathrm{C}-15 \mathrm{~min} ; 95^{\circ} \mathrm{C}-15 \mathrm{~s} ; 60^{\circ} \mathrm{C}-30 \mathrm{~s} ; 72^{\circ} \mathrm{C}-20 \mathrm{~s}$ \\
\hline TIMP2 & $\begin{array}{l}\text { Forward } \\
\text { Reverse }\end{array}$ & $\begin{array}{l}\text { GCAACAGGCGTTTTGCAATG } \\
\text { CGGAATCCACCTCCTTCTCG }\end{array}$ & $95^{\circ} \mathrm{C}-15 \mathrm{~min} ; 95^{\circ} \mathrm{C}-15 \mathrm{~s} ; 60^{\circ} \mathrm{C}-30 \mathrm{~s} ; 72^{\circ} \mathrm{C}-20 \mathrm{~s}$ \\
\hline RECK & $\begin{array}{l}\text { Forward } \\
\text { Reverse }\end{array}$ & $\begin{array}{l}\text { CCTCAGTGAGCACAGTTCAGA } \\
\text { CCTGTGGCATCCACGAAACT }\end{array}$ & $95^{\circ} \mathrm{C}-15 \mathrm{~min} ; 95^{\circ} \mathrm{C}-15 \mathrm{~s} ; 60^{\circ} \mathrm{C}-30 \mathrm{~s} ; 72^{\circ} \mathrm{C}-20 \mathrm{~s}$ \\
\hline FAK & $\begin{array}{l}\text { Forward } \\
\text { Reverse }\end{array}$ & $\begin{array}{c}\text { TCC ACC AAA GAA ACC ACC TC } \\
\text { ACG GCT TGA CAC CCT CAT T }\end{array}$ & $95^{\circ} \mathrm{C}-15 \mathrm{~min} ; 95^{\circ} \mathrm{C}-15 \mathrm{~s} ; 60^{\circ} \mathrm{C}-30 \mathrm{~s} ; 72^{\circ} \mathrm{C}-20 \mathrm{~s}$ \\
\hline Src & $\begin{array}{l}\text { Forward } \\
\text { Reverse }\end{array}$ & $\begin{array}{l}\text { TCGTGAGGGAGAGTGAGAC } \\
\text { GCGGGAGGTGATGTAGAAAC }\end{array}$ & $95^{\circ} \mathrm{C}-15 \mathrm{~min} ; 95^{\circ} \mathrm{C}-15 \mathrm{~s} ; 60^{\circ} \mathrm{C}-30 \mathrm{~s} ; 72^{\circ} \mathrm{C}-20 \mathrm{~s}$ \\
\hline Integrin $\beta 1$ & $\begin{array}{l}\text { Forward } \\
\text { Reverse }\end{array}$ & $\begin{array}{l}\text { TATCCTCCTGAGCGCCTTT } \\
\text { TGGCCTTTTGAAGAATCCAA }\end{array}$ & $95^{\circ} \mathrm{C}-15 \mathrm{~min} ; 95^{\circ} \mathrm{C}-15 \mathrm{~s} ; 60^{\circ} \mathrm{C}-30 \mathrm{~s} ; 72^{\circ} \mathrm{C}-20 \mathrm{~s}$ \\
\hline$\beta$-actin & $\begin{array}{l}\text { Forward } \\
\text { Reverse }\end{array}$ & $\begin{array}{l}\text { TCTTGGGTATGGAATCCTGTG } \\
\text { AGGTCTTTACGGATGTCAACG }\end{array}$ & $95^{\circ} \mathrm{C}-15 \mathrm{~min} ; 95^{\circ} \mathrm{C}-15 \mathrm{~s} ; 60^{\circ} \mathrm{C}-30 \mathrm{~s} ; 72^{\circ} \mathrm{C}-20 \mathrm{~s}$ \\
\hline
\end{tabular}

carried out in a total of $10 \mu \mathrm{l}$, containing PowerUp ${ }^{\mathrm{TM}} \mathrm{SYBR}^{\mathrm{TM}}$ Green Master Mix $2 \times(5 \mu \mathrm{l})$ (Applied Biosystems, Foster City, CA, USA), $0.4 \mu \mathrm{M}$ of each primer, $50 \mathrm{ng}$ of cDNA and nuclease free $\mathrm{H}_{2} \mathrm{O}$. Results were expressed as relative amounts of the target gene using $\beta$ actin as inner reference gene (housekeeping gene), using the cycle threshold $(\mathrm{Ct})$ method. Primers and details are described in Table 1.

\subsection{Activities of MMP were determined by a gelatin proteolysis-based zymography}

The proteolytic activities of MMP-2 and MMP-9 in conditioned medium were assayed by gelatin-based zymography, widely used for this end. Conditioned medium was collected in response to the titanium surfaces or by cells in response to PP1 $(5 \mu \mathrm{M})$, and later it was clarified by centrifugation $13,200 \mathrm{~g}$ for $15 \mathrm{~min}$ at $4{ }^{\circ} \mathrm{C}$, and stored at $-20^{\circ} \mathrm{C}$. Samples were quantified using the Lowry protein assay (Lowry et al., 1956) and diluted in non-reducing buffer (0.1 M Tris-HCl, pH 6.8, 20\% (v/v) glycerol, $1 \%$ (w/v) SDS, and $0.001 \%$ $(\mathrm{w} / \mathrm{v})$ bromophenol blue). Equal amounts of protein $(75 \mu \mathrm{g})$ were loaded onto SDS-polyacrylamide gel $(10 \%(\mathrm{w} / \mathrm{v}))$ and $4 \%(\mathrm{w} / \mathrm{v})$ gelatin. MMPs renaturation was performed in $2 \%(\mathrm{v} / \mathrm{v})$ Triton X100 for $40 \mathrm{~min}$ followed by incubation in incubation buffer [ $50 \mathrm{mM}$ Tris- $\mathrm{HCl}$ and $10 \mathrm{mM} \mathrm{CaCl} 2\left(\mathrm{pH} \mathrm{7.4)]} \mathrm{at} 37^{\circ} \mathrm{C}\right.$ for $18 \mathrm{~h}$. Afterwards, gels were stained with $0.5 \%(\mathrm{w} / \mathrm{v})$ coomassie blue $\mathrm{G} 250$ for $30 \mathrm{~min}$, washed in a $30 \%(\mathrm{v} / \mathrm{v})$ methanol and $10 \%(\mathrm{v} / \mathrm{v})$ glacial acetic acid solution and then analyzed using ImageJ software.

\subsection{Statistical analysis}

Mean values and standard deviation obtained for each test were calculated, and one-way ANOVA was performed (alpha error type set to 0.05) when appropriate, with Bonferroni corrected post-test, or non-parametric analysis, using GraphPad Prysm 5 (GraphPad Software, USA).

\section{Results}

As reported previously elsewhere [17], there are considerable differences in the topography of the titanium-based surfaces evaluated in this study, mainly documented by atomic force microscopy (insert in Fig. 1). The topography modifications were decisive for wettability, which significantly impacts water contact angle $(\mathrm{Mc}=81.41 \pm 0.01 ; \mathrm{DAE}=97.18 \pm 0.01 ; \mathrm{nHA}=40.95 \pm 0.02)$.
3.1. Biointerface between pre-osteoblast and titanium-modified surfaces requires reprogramming of dynamic adhesion-related genes

Thereafter, we started with the biological characterization by seeding pre-osteoblast on all of those surfaces and after $24 \mathrm{~h}$ of seeding. The pre-osteoblast morphology was evaluated to predict the quality of the pre-osteoblast/surface interactions (Fig. 1b,d,f). Pre-osteoblast performed better on DAE or nHA at this stage, as they completely spread on the both surfaces (Fig. 1d,f). To investigate whether the integrin-downstream pathway (Fig. 2a) was required, the pre-osteoblast was seed on the surfaces, and $24 \mathrm{~h}$ later the biological samples were harvested in order to study specific genes. Curiously, there was a significant decrease on the integrin$ß 1$ expression in response to DAE and $\mathrm{nHA}$ (Fig. 2b). A similar profile was also found for FAK and Src genes (Fig. 2c,d). Elsewhere, we reported a significant activation of Src and FAK in response to the same surfaces [17] and suggested the down-modulation of those genes might be regulated by a negative feedback. To validate this hypothesis, we treated the pre-osteoblast with a well-documented Src inhibitor (PP1), which promoted a significant down-regulation of Src at Y416 (Fig. 2e). Our results confirmed a strong feedback of the Src activity on the integrin-based pathway, because integrinß1 ( $\sim$-fold changes), FAK ( $\sim 12$-fold changes), and Src ( $\sim 3.5$-fold changes) were significantly up-expressed when Src was chemically inhibited (Fig. 2f-h). Here, cells not treated with PP1, but with vehicle, were considered the control.

\subsection{Titanium-modified surfaces differentially orchestrate ECM remodeling-related genes}

The titanium-related surfaces modulated the cell morphology and adhesion up to $24 \mathrm{~h}$; therefore, we decided to explore their relationship with the surfaces. MMPs and TIMPs were significantly involved in the establishment of the adequate biointerface for the osteoblast phenotype (Fig. 3a-e). Our results found increasing of MMP activities in response to both DAE and nHA (Fig. $3 \mathrm{f}-\mathrm{j}$ ), and this biological effect is guaranteed by the significant decrease of tissueinhibitor matrix metaloproteinases: TIMP1, TIMP2, and RECK (Fig. 3c-e, respectively). As suggested previously for osteoblast adhesion, when MMPs-2 and -9 activities increase in the extracellular compartment, ECM remodeling-related genes seems to establish negative feedback on their respective MMP gene activation because both of them significantly decreased in response to DAE and nHA. 

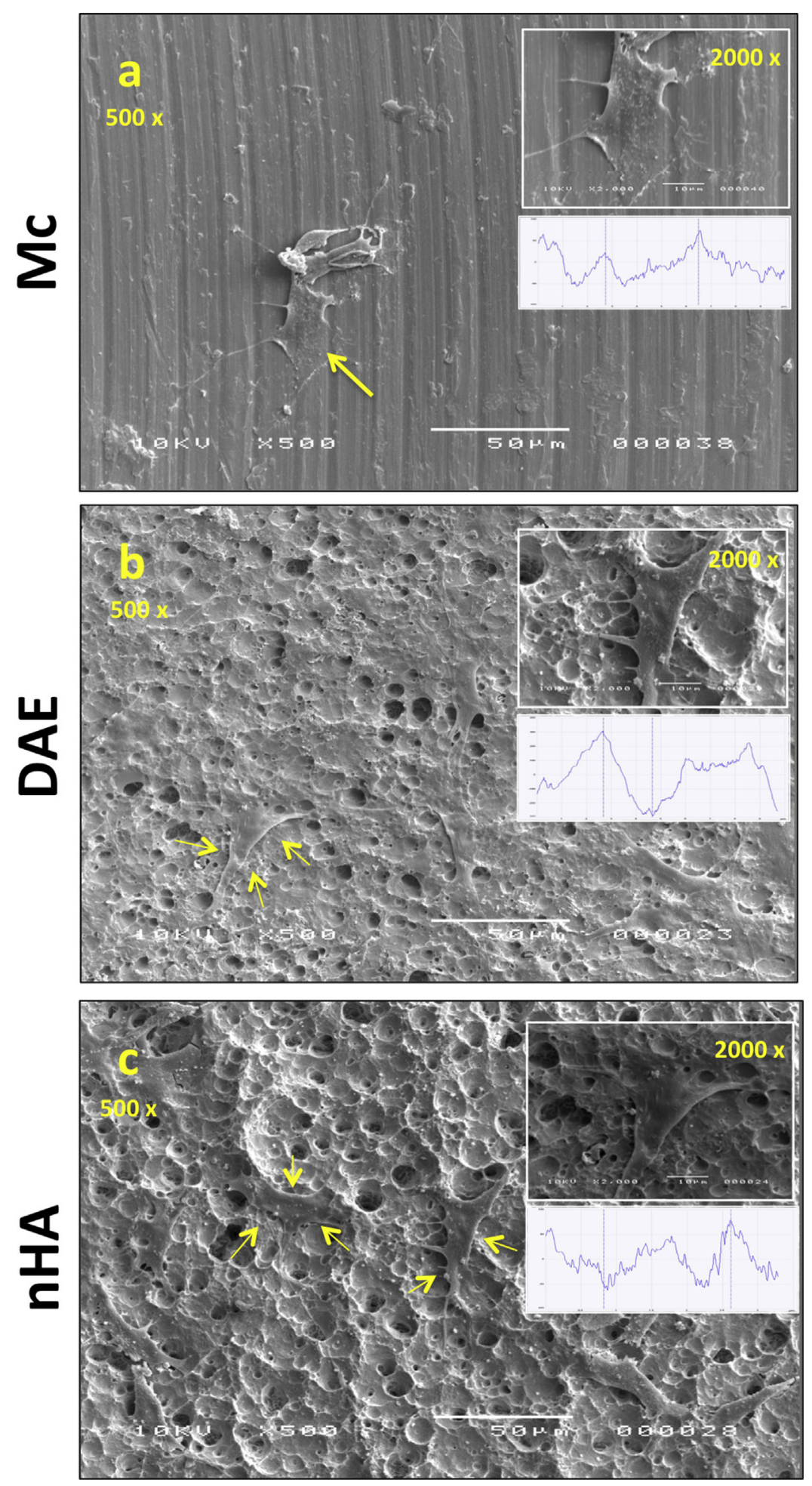

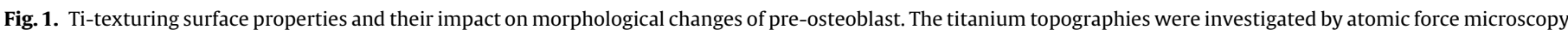

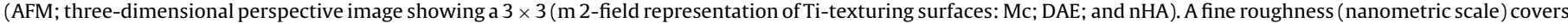

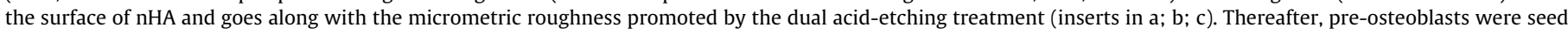

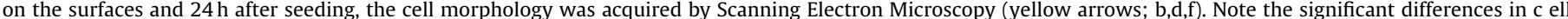

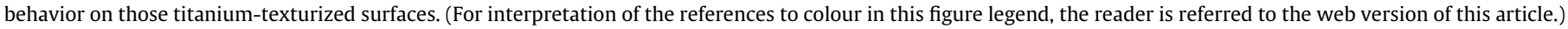

\subsection{Src and ECM remodeling-related genes are hallmarks of direct and indirect effects of titanium-modified surfaces on pre-osteoblast behavior during osteogenic phenotype}

In bone, it has been reported that ECM remodeling and SrC are decisive during osteoblast differentiation [18,19]. Previously, we showed titanium-modified surfaces stimulate osteoblast differentiation in a direct contact manner. By exploring the same biological model (Fig. 4a), we found here a significant increase of Src gene expression (Fig. 4b), suggesting a direct feedback of the Src activity, which decreased as a pre-requisite for osteogenic phenotype [20]. On the other hand, in an indirect contact man- 
a

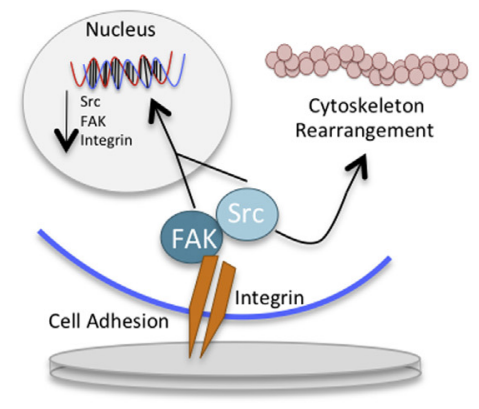

b

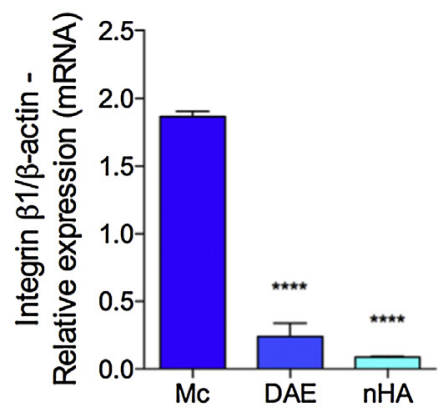

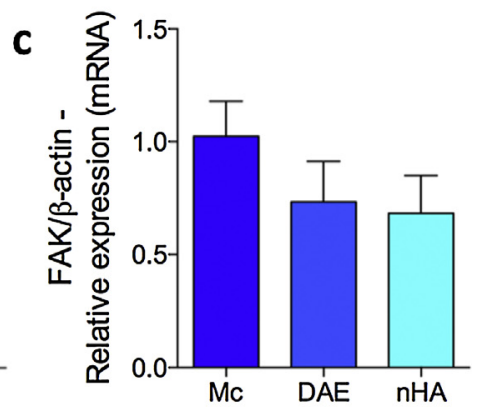

d
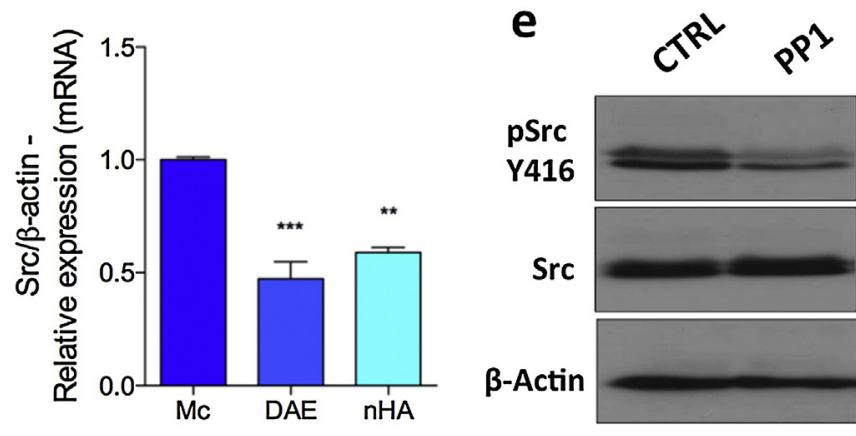

$60 \mathrm{kDa}$

$60 \mathrm{kDa}$

$37 \mathrm{kDa}$
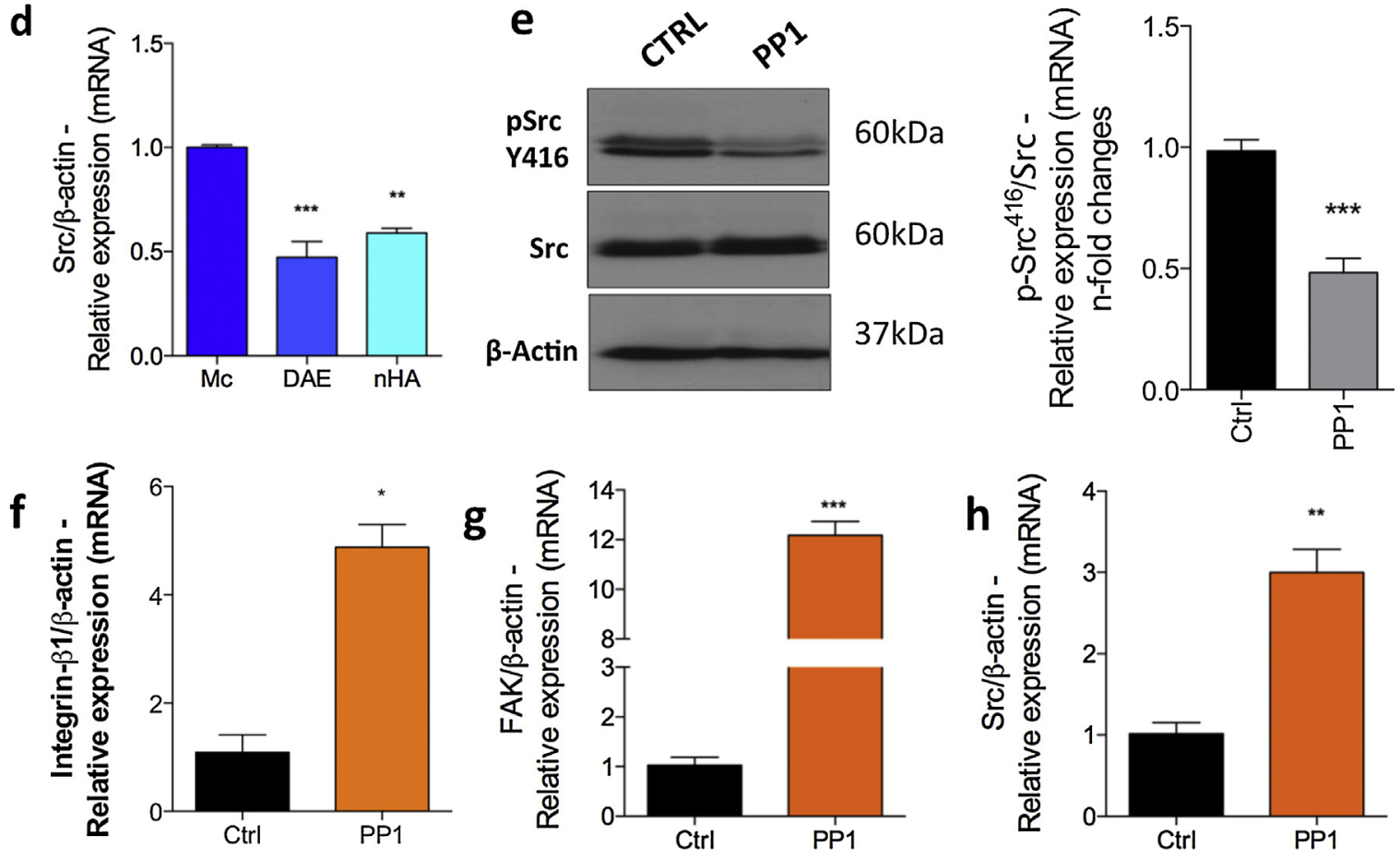

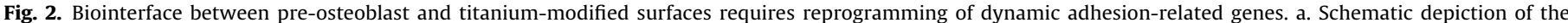

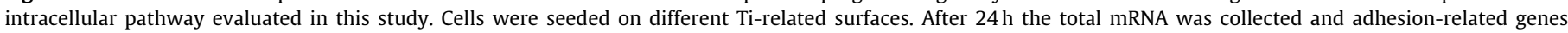

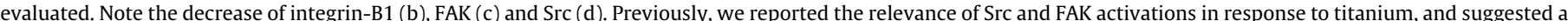

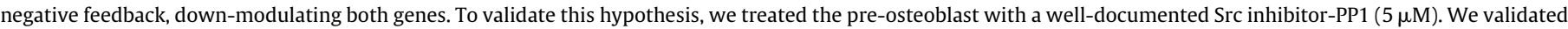

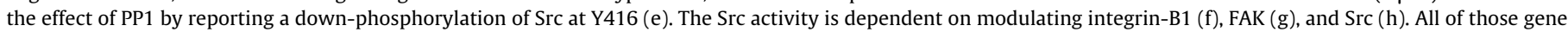
activations were evaluated by qPCR. The differences were significant when $\mathrm{p}<0.05$.

ner, Src gene expression significantly decreased in response to DAE and nHA (Fig. 4c). Next, we investigated ECM-related gene MMPs and their tissue inhibitors in both direct and indirect manner up to 14 days in vitro (Fig. 4). Curiously, all of the genes investigated were significantly up-modulated in response to DAE and nHA in a direct contact manner - specifically, MMP-2 and MMP-9 were up-modulated $\sim 4$ and $\sim 10$-fold changes, respectively, in response to DAE (Fig. 4d,e) and $\sim 2$ and $\sim 2.5$-fold changes, respectively, in response to nHA (Fig. 4d,e); while TIMP1 had $\sim 10$ and $\sim 2.5$-fold changes, in response to DAE (Fig. 4f) and nHA (Fig. 4f), respectively. TIMP2 had $\sim 20$ and $\sim 10$-fold changes, in response to DAE and nHA (Fig. 4g), respectively. In addition, RECK, a membrane GPI-anchored protein, increased $\sim 2.5$-fold changes in response to DAE (Fig. $4 \mathrm{~h}$ ), while it significantly decreased in response to nHA (Fig. 4h). All of these analyses were made in comparison with Machined (Mc) surfaces.

Considering the indirect contact, we also found a decreased expression of the gene MMP-2 in response to both DAE and nHA, when compared with Mc (Fig. 4i). In addition, modulation of MMP9 depended on material properties; significantly increased $(\sim 2$-fold changes) in response to DAE and significantly decreased in response to nHA (Fig. 4j). TIMP1 slightly but not significantly increased (Fig. 4k). However, TIMP2 was significantly up-modulated, reaching 20-fold change in response to DAE, and had an almost 10 -fold increased in response to nHA (Fig. 4l); while RECK was significantly decreased (Fig. $4 \mathrm{~m}$ ).

Importantly, we showed that PP1-inhibition of Src promoted a significant increase of both MMP expression (Fig. 5a,b) and activity (c,f).

\section{Discussion}

Over the last 10 years, we have searched for alternative methods to understand the molecular biocompatibility of gold-standard biomaterials to guide biomedical engineering and reduce the number of experimental animals. In this sense, we have proposed cell signaling as a dynamic field to be considered [21,22]. In this work, three different surfaces were assayed: Machined (Mc), Dual acid-etching (DAE), and nano hydroxyapatite-blasted (nHA) groups. The nHA was obtained by adsorbing nanometer-scaled hydroxyapatite on the DAE-modified titanium surfaces [17,23]. First, the topography differences were characterized by atomic 

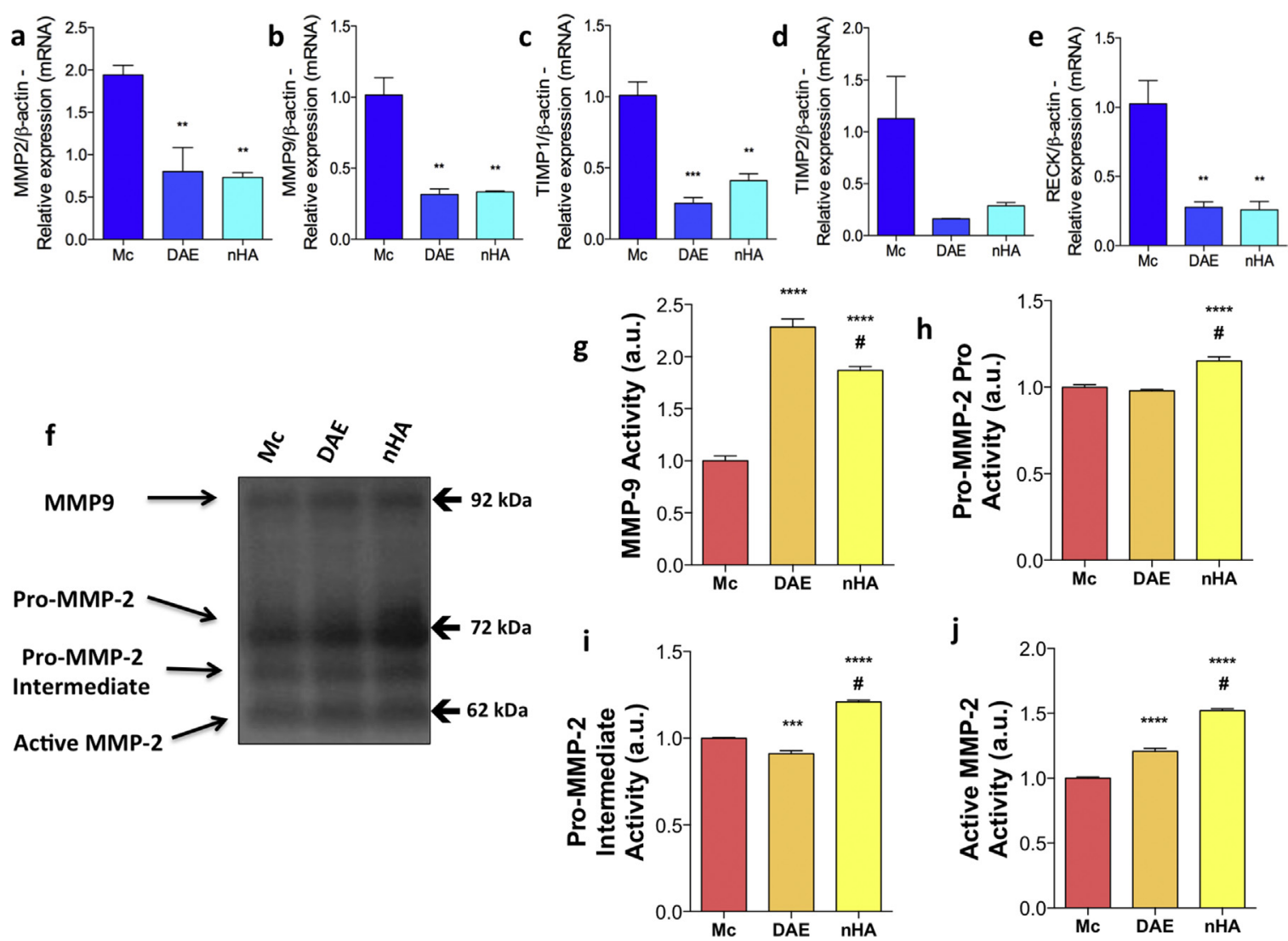

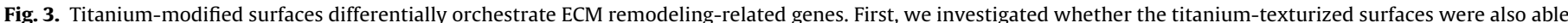

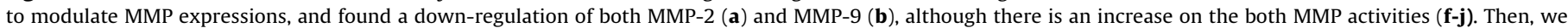

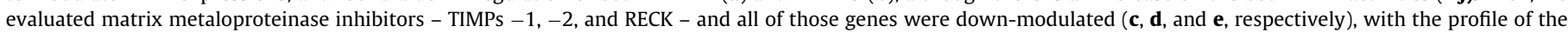
activation very similar between DAE and $\mathrm{nHA}$. The differences were significant when $\mathrm{p}<0.05$.

force microscopy and corroborated with those obtained previously by Bezerra et al. (2017). Thereafter, we investigated whether the topography could modulate pre-osteoblast morphological changes. The pre-osteoblast performed better on the nHA surfaces, maybe because this surface had a higher hydrophilicity than others, indicated by its smaller water contact angle. Another point to consider is the capacity of titanium-texturized surfaces to adsorb serum protein, which is able to cause profound cell metabolic changes, as suggested by Zambuzzi's group [22,24].

In sequence, we investigated the molecular fingerprint of the biointerfaces promoted by titanium-modified surfaces, mainly related to cell adhesion $(24 \mathrm{~h})$ and differentiation (10 days). The adhesion-related gene reprogramming revealed a significant decrease in integrin and Src expression in response to DAE and nHA. A reasonable explanation is that Src activity is significantly required during osteoblast adhesion on those surfaces and results in a negative feedback on Src expression. To obtain a better understanding of the participation of Src in this process, pre-osteoblasts were treated up to $24 \mathrm{~h}$ with PP1, a chemical Src-inhibitor, and the gene expression of integrin, FAK, and Src were reevaluated. The significant increase of the Integrin, FAK, and Src expression by chemically Src-inhibited pre-osteoblasts validated our hypothesis. In addition, as integrin and FAK are required for later Src activation, this increase in gene expression can be understood as a compensation mechanism for the maintenance of intracellular Src levels, because Src governs important intracellular pathways in osteoblast metabolism $[7,20,25]$. In addition, ECM remodelingrelated genes were also evaluated. Our data showed that MMP activity is a titanium surface-dependent, where nHA stimulated higher MMP-2 and -9 activities of the released MMPs by activate osteoblasts, while their genes were down-regulated in response to both DAE and nHA. According to the same reasonable explanation used earlier, the high activity of MMP might promote a compensation feedback decreasing both MMP transcripts evaluated by qPCR technology. TIMPs were also down-regulated, favoring MMP activity presented. A possible mechanism suggests the involvement of integrin-dependent Src function during osteoblast adhesion, which can be considered a prerequisite to ECM-related genes.

Later, to analyze the possible involvement of Src and ECM remodeling process during the osteogenic phenotype acquisition, pre-osteoblastic cells were maintained in culture up to 10 days using two experimental strategies, direct and indirect contact. Src expression was higher in response to osteoblast under a direct adhesion on the titanium than those cells grown in a titaniumenriched medium, in indirect contact. Elsewhere we showed that titanium-based dental implants release considerable titanium amount when incubated in cell medium up to $24 \mathrm{~h}$ in $\mathrm{CO}_{2}$ incubator [23]. This titanium-enriched medium promotes a considerable increase on Reactive Oxygen Species (ROS), culminating on phosphorylation balance governed by the decrease of the PTP activities (since PTPs have cysteine in the enzymatic active-site and Cysresidue is very sensitive to oxidation) [23,26-28]. In addition, Fernandes et al. [26] found that ROS production is necessary during the first hours of pre-osteoblast adhesion and it guaranteed FAK and Src phosphorylations as an immediate consequence of the PTP oxidation.

In addition, we have proposed Src as indispensable transducers for osteoblast metabolism, governing their differentiation and osteogenic phenotype [7]. Previously, we found that Src activity decreases significantly (decrease of phosphoY416 and increase of 

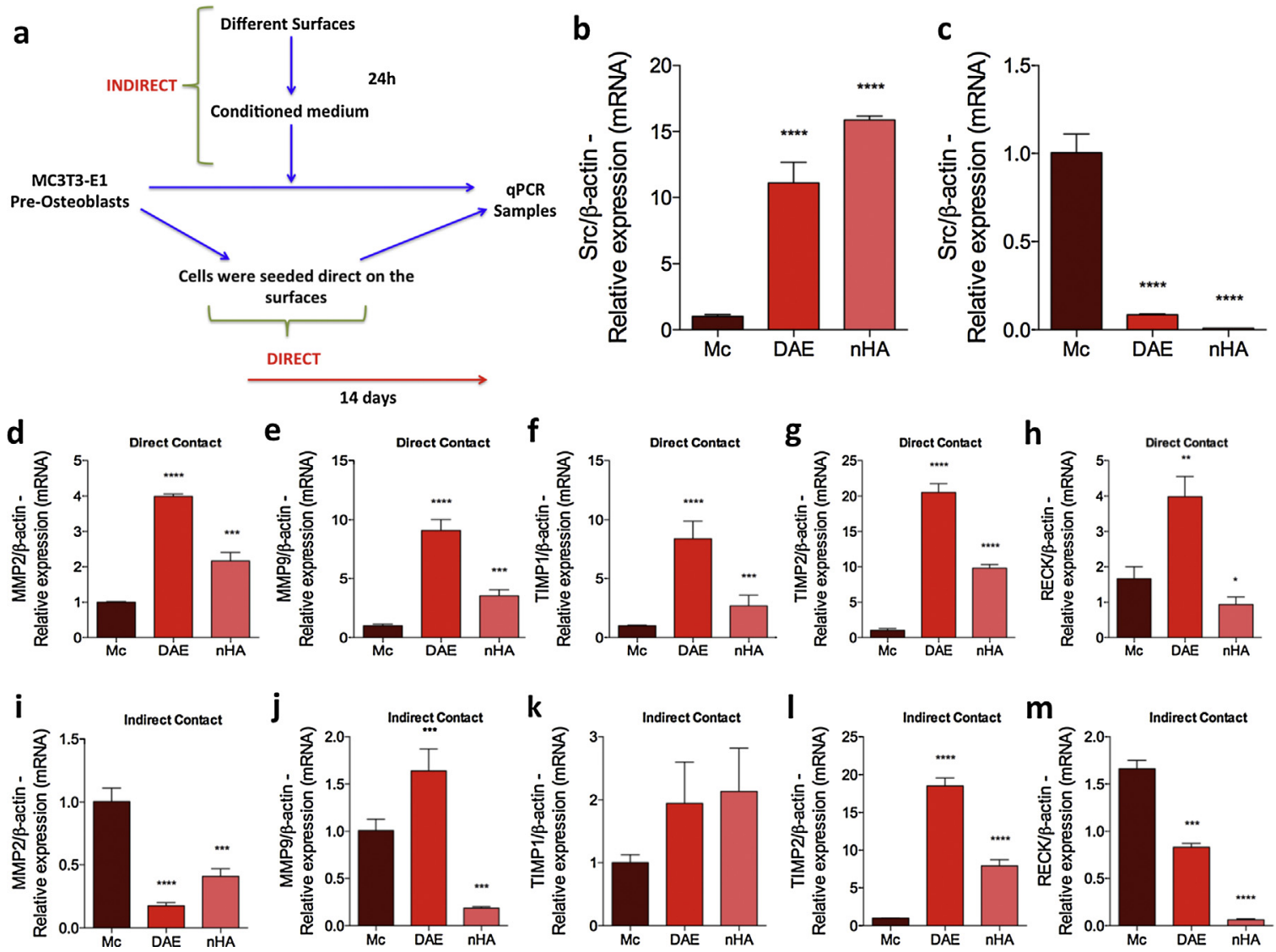

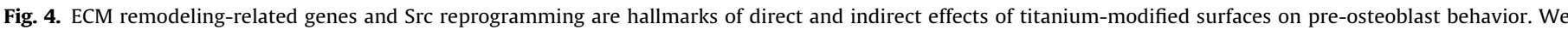

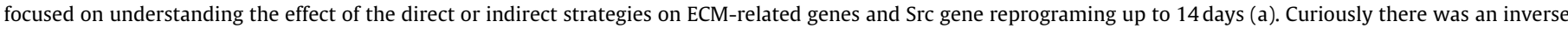

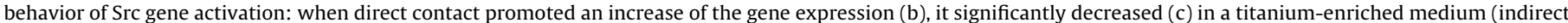

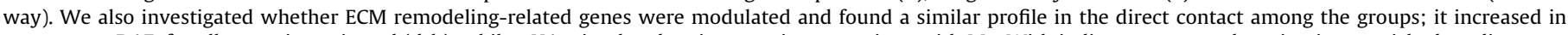

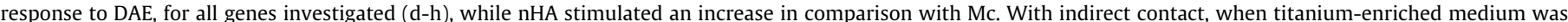

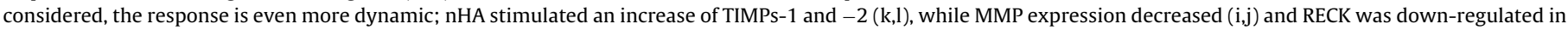
response to both DAE and $\mathrm{nHA}(\mathrm{m})$. The differences were significant when $\mathrm{p}<0.05$.
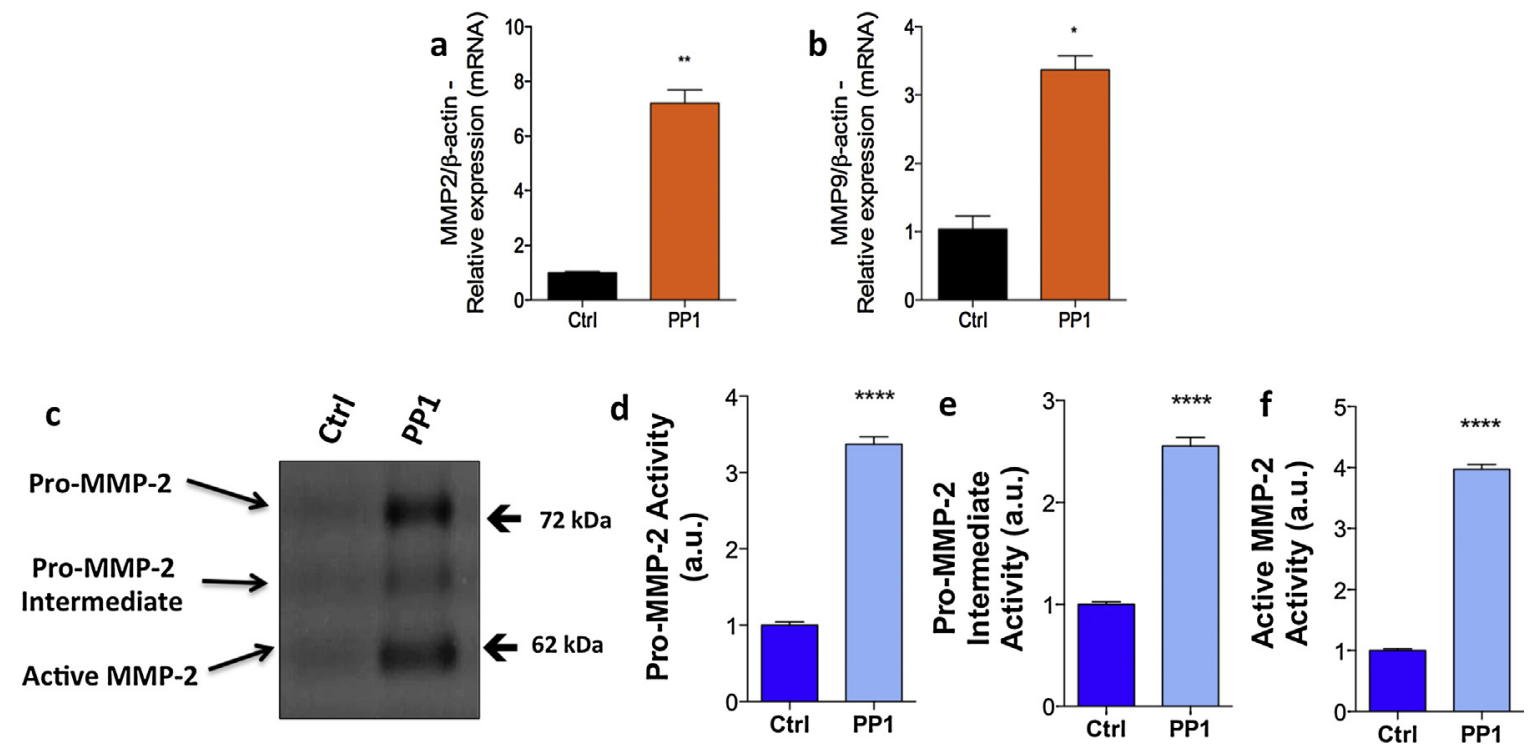

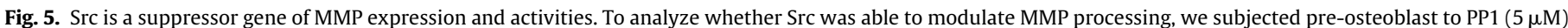

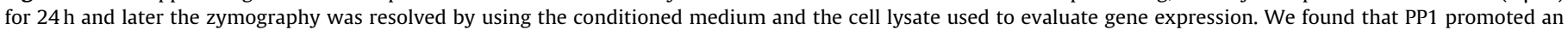
increase of both expression (a,b) and activities (c-f). The differences were significant when $\mathrm{p}<0.05$. 
phosphor-Y527) during osteoblast differentiation. Since osteoblast differentiation requires Src inhibition and nHA promotes osteoblast differentiation [17], we suggested the up-expression of the Src was due to compensation feedback, as reported earlier for Src during osteoblast adhesion (up to $24 \mathrm{~h}$ ) and MMPs. Importantly, we demonstrated that Src is necessary to govern cytoskeletal remodeling during osteoblast morphological changes [29].

Altogether these results demonstrate the crucial role of intracellular Src in ECM remodeling, and maybe a prerequisite to processing MMP. Thus, it is clear that Src performs a distinct role during osteoblast adhesion and differentiation.

\section{Conclusion}

This study showed that the molecular hallmarks involved with the pre-osteoblast relationship with different topography-based biointerface can govern Src-dependent osteoblast metabolism as a pre-requisite to ECM remodeling.

\section{Competing financial interests}

The authors declare no competing financial interests.

\section{Acknowledgements}

We would like to thank FAPESP (grant 2014/22689-3) and CNPq (Proc. Nr. 301966/2015-0) for the financial support. The authors are grateful to Dr. Giselle N. Fontes for her technical assistance with the AFM images and SIN Implants Co.

\section{References}

[1] K. Hamad, M. Kon, T. Hanawa, K. Yokoyama, Y. Miyamoto, K. Asaoka, Hydrothermal modification of titanium surface in calcium solutions, Biomaterials 23 (2002) 2265-2272.

[2] P.G. Coelho, R. Jimbo, Osseointegration of metallic devices: current trends based on implant hardware design, Arch. Biochem. Biophys. 561 (2014) 99-108, http://dx.doi.org/10.1016/j.abb.2014.06.033.

[3] Y. Dang, L. Zhang, W. Song, B. Chang, T. Han, Y. Zhang, L. Zhao, In vivo osseointegration of $\mathrm{Ti}$ implants with a strontium-containing nanotubular coating, Int. J. Nanomed. 11 (2016) 1003-1011, http://dx.doi.org/10.2147/IJN. S102552.

[4] P. Trisi, M. Berardini, A. Falco, E. Sandrini, M.P. Vulpiani, A new highly hydrophilic electrochemical implant titanium surface: a histological and biomechanical In vivo study, Implant Dent. 26 (2017) 429-437, http://dx.doi. org/10.1097/ID.0000000000000605.

[5] X.-Q. Fang, X.-F. Liu, L. Yao, C.-Q. Chen, J.-F. Lin, Z.-D. Gu, P.-H. Ni, X.-M. Zheng, Q.-S. Fan, Focal adhesion kinase regulates the phosphorylation protein tyrosine phosphatase-alpha at Tyr789 in breast cancer cells, Mol. Med. Rep. 11 (2015) 4303-4308, http://dx.doi.org/10.3892/mmr.2015.3262.

[6] L. Chen, K. Shi, C.E. Frary, N. Ditzel, H. Hu, W. Qiu, M. Kassem, Inhibiting actin depolymerization enhances osteoblast differentiation and bone formation in human stromal stem cells, Stem Cell Res. 15 (2015) 281-289, http://dx.doi. org/10.1016/j.scr.2015.06.009.

[7] W.F. Zambuzzi, R. Milani, A. Teti, Expanding the role of Src and protein-tyrosine phosphatases balance in modulating osteoblast metabolism: lessons from mice, Biochimie 92 (2010) 327-332, http://dx.doi.org/10.1016/j. biochi.2010.01.002.

[8] Z. Sun, S.S. Guo, R. Fassler, Integrin-mediated mechanotransduction, J. Cell Biol. 215 (2016) 445-456, http://dx.doi.org/10.1083/jcb.201609037.

[9] H.Y. Kueh, W.M. Brieher, T.J. Mitchison, Dynamic stabilization of actin filaments, Proc. Natl. Acad. Sci. U. S. A. 105 (2008) 16531-16536, http://dx.doi. org/10.1073/pnas.0807394105.

[10] I. Nishimura, Genetic networks in osseointegration, J. Dent. Res. 92 (2013) 109S-118S, http://dx.doi.org/10.1177/0022034513504928.

[11] V.I. Shubayev, R. Branemark, J. Steinauer, R.R. Myers, Titanium implants induce expression of matrix metalloproteinases in bone during osseointegration, J. Rehabil. Res. Dev. 41 (2004) 757, http://dx.doi.org/10. 1682/JRRD.2003.07.0107.
[12] H.K. Rooprai, A.J. Martin, A. King, U.D. Appadu, H. Jones, R.P. Selway, R.W. Gullan, G.J. Pilkington, Comparative gene expression profiling of ADAMs, MMPs, TIMPs, EMMPRIN, EGF-R and VEGFA in low grade meningioma, Int. J. Oncol. 49 (2016) 2309-2318, http://dx.doi.org/10.3892/ijo.2016.3739.

[13] K.B.S. Paiva, J.M. Granjeiro, Bone tissue remodeling and development: focus on matrix metalloproteinase functions, Arch. Biochem. Biophys. 561 (2014) 74-87, http://dx.doi.org/10.1016/j.abb.2014.07.034.

[14] W.F. Zambuzzi, C.L. Yano, A.D.M. Cavagis, M.P. Peppelenbosch, J.M. Granjeiro, C.V. Ferreira, Ascorbate-induced osteoblast differentiation recruits distinct MMP-inhibitors: RECK and TIMP-2, Mol. Cell. Biochem. 322 (2009) 143-150, http://dx.doi.org/10.1007/s11010-008-9951-x.

[15] M. Gottlander, C.B. Johansson, A. Wennerberg, T. Albrektsson, S. Radin, P. Ducheyne, Bone tissue reactions to an electrophoretically applied calcium phosphate coating, Biomaterials 18 (1997) 551-557.

[16] L. Meirelles, A. Arvidsson, M. Andersson, P. Kjellin, T. Albrektsson, A. Wennerberg, Nano hydroxyapatite structures influence early bone formation, J. Biomed. Mater. Res. A 87 (2008) 299-307, http://dx.doi.org/10.1002/jbm.a. 31744.

[17] F. Bezerra, M.R. Ferreira, G.N. Fontes, C.J. da Costa Fernandes, D.C. Andia, N.C. Cruz, R.A. da Silva, W.F. Zambuzzi, Nano hydroxyapatite-blasted titanium surface affects pre-osteoblast morphology by modulating critical intracellular pathways., Biotechnol, Bioeng. 114 (2017) (2017) 1888-1898, http://dx.doi. org/10.1002/bit.26310.

[18] T. Accorsi-Mendonca, K.B. da S. Paiva, W.F. Zambuzzi, T.M. Cestari, V.S. Lara, M.C. Sogayar, R. Taga, J.M. Granjeiro, Expression of matrix metalloproteinases-2 and -9 and RECK during alveolar bone regeneration in rat, J. Mol. Histol. 39 (2008) 201-208, http://dx.doi.org/10.1007/s10735-0079152-z.

[19] W.F. Zambuzzi, A. Bruni-Cardoso, J.M. Granjeiro, M.P. Peppelenbosch, H.F. de Carvalho, H. Aoyama, C.V. Ferreira, On the road to understanding of the osteoblast adhesion: cytoskeleton organization is rearranged by distinct signaling pathways, J. Cell. Biochem. 108 (2009) 134-144, http://dx.doi.org/ $10.1002 / \mathrm{jcb} .22236$.

[20] C. Palumbo, M. Ferretti, A. De Pol, Apoptosis during intramembranous ossification, J. Anat. 203 (2003) 589-598, http://dx.doi.org/10.1046/j.14697580.2003.00247.x.

[21] C.J. da Costa Fernandes, A.S. do Nascimento, R.A. da Silva, W.F. Zambuzzi, Fibroblast contributes for osteoblastic phenotype in a MAPK-ERK and sonic hedgehog signaling-independent manner, Mol. Cell Biochem. 436 (2017) 111-117, http://dx.doi.org/10.1007/s11010-017-3083-0.

[22] B.C.J. van der Eerden, A. Teti, W.F. Zambuzzi, Bone, a dynamic and integrating tissue, Arch. Biochem. Biophys. 561 (2014) 1-2, http://dx.doi.org/10.1016/j. abb.2014.08.012.

[23] M.C. Rossi, F.J.B. Bezerra, R.A. Silva, B.P. Crulhas, C.J.C. Fernandes, A.S. Nascimento, V.A. Pedrosa, P. Padilha, W.F. Zambuzzi, Titanium-released from dental implant enhances pre-osteoblast adhesion by ROS modulating crucial intracellular pathways, J. Biomed. Mater. Res. A. 105 (2017) 2968-2976, http://dx.doi.org/10.1002/jbm.a.36150.

[24] W.F. Zambuzzi, G.V.O. Fernandes, F.G. Iano, M. da, S. Fernandes, J.M. Granjeiro, R.C. Oliveira, Exploring anorganic bovine bone granules as osteoblast carriers for bone bioengineering: a study in rat critical-size calvarial defects, Braz. Dent. J. 23 (2012) 315-321.

[25] W.F. Zambuzzi, J.M. Granjeiro, K. Parikh, S. Yuvaraj, M.P. Peppelenbosch, C.V. Ferreira, Modulation of Src activity by low molecular weight protein tyrosine phosphatase during osteoblast differentiation, Cell. Physiol. Biochem. 22 (2008) 497-506, http://dx.doi.org/10.1159/000185506.

[26] G.V.O. Fernandes, A.D.M. Cavagis, C.V. Ferreira, B. Olej, M. de S. Leao, C.L. Yano, M. Peppelenbosch, J.M. Granjeiro, W.F. Zambuzzi, Osteoblast adhesion dynamics: a possible role for ROS and LMW-PTP, J. Cell. Biochem. 115 (2014) 1063-1069, http://dx.doi.org/10.1002/jcb.24691.

[27] S. Bertazzo, W.F. Zambuzzi, D.D.P. Campos, T.L. Ogeda, C.V. Ferreira, C.A. Bertran, Hydroxyapatite surface solubility and effect on cell adhesion, Colloids Surf. B Biointerfaces 78 (2010) 177-184, http://dx.doi.org/10.1016/j. colsurfb.2010.02.027.

[28] S. Gemini-Piperni, R. Milani, S. Bertazzo, M. Peppelenbosch, E.R. Takamori, J.M. Granjeiro, C.V. Ferreira, A. Teti, W. Zambuzzi, Kinome profiling of osteoblasts on hydroxyapatite opens new avenues on biomaterial cell signaling, Biotechnol. Bioeng. 111 (2014) 1900-1905, http://dx.doi.org/10. 1002 /bit.25246.

[29] A. Marumoto, R. Milani, R.A. da Silva, C.J. da Costa Fernandes, J.M. Granjeiro, C.V. Ferreira, M.P. Peppelenbosch, W.F. Zambuzzi, Phosphoproteome analysis reveals a critical role for hedgehog signalling in osteoblast morphological transitions, Bone 103 (2017) 55-63, http://dx.doi.org/10.1016/j.bone.2017.06. 012. 